\title{
Notes on the vocalizations of Blue-winged Mountain-tanager (Anisognathus somptuosus) and Bolivian Mountain-tanager (Anisognathus flavinucha)
}

Peter Boesman

In the following we briefly analyze and compare voice of Blue-winged Mountain-tanager (Anisognathus somptuosus) and Bolivian Mountain-tanager (Anisognathus flavinucha). We also try to quantify the extent of any vocal differences using the criteria proposed by Tobias et al. (2010), as a support for taxonomic review. We have made use of sound recordings available on-line from Xeno Canto (XC).

A comparison of song of both species, illustrated with sonograms:
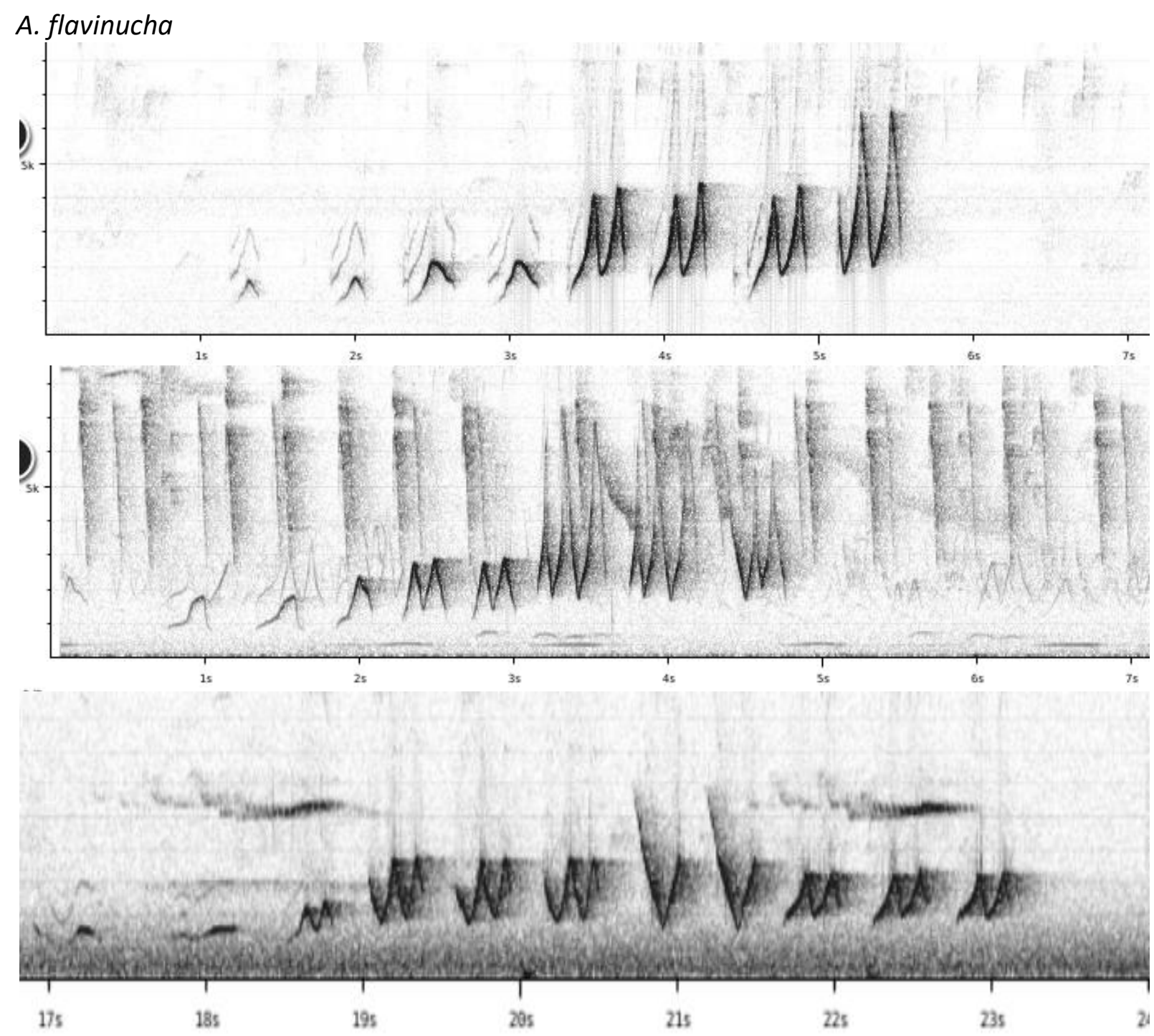

(the latter is the most northern recording, from Marcapata, Cuzco; XC22804) 


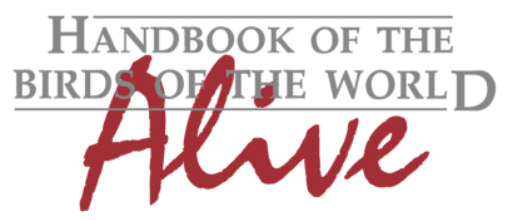

\section{ORNITHOLOGICAL NOTES}

\section{A. somptuosus}

Vocalizations are quite variable, and true song rarely recorded. Some examples:
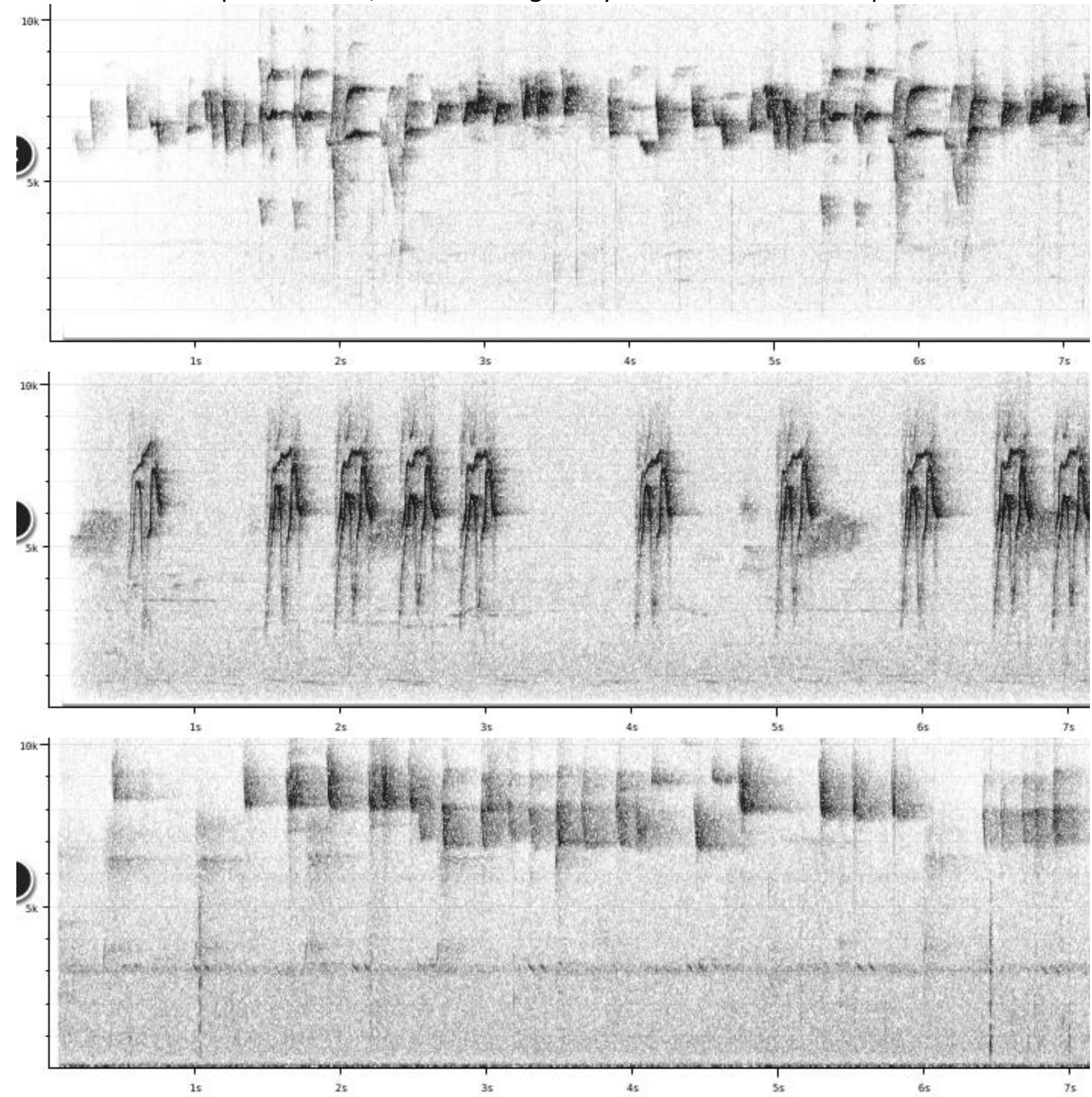

Song of both related species couldn't be more different, $A$. flavinucha having a song of about 7-11 low-pitched rich melodious whistles starting at low volume and gradually getting louder, while $A$. somptuosus has only high-pitched twittering vocalizations without much structure. Based on e.g. number of notes per song phrase (3) and minimum frequency (3) total vocal score is about 6 . 
This note was finalized on 5th July 2016, using sound recordings available on-line at that moment. We would like to thank in particular the sound recordists who placed their recordings for this species on XC: Peter Boesman, Tayler Brooks, Diego Calderon, Paul Coopmans, Thomas Donegan, Jerome Fischer, Ross Gallardy, David Geale, Niels Krabbe, Dan Lane, Mitch Lysinger, Oscar Marin Gomez, John V Moore, Jonas Nilsson, Andrew Spencer, Martin St-Michel, Gary Stiles, Joseph Tobias and Herman Van Oosten.

\section{References}

Tobias, J.A., Seddon, N., Spottiswoode, C.N., Pilgrim, J.D., Fishpool, L.D.C. \& Collar, N.J. (2010). Quantitative criteria for species delimitation. Ibis 152(4): 724-746.

\section{Recommended citation}

Boesman, P. (2016). Notes on the vocalizations of Blue-winged Mountain-tanager (Anisognathus somptuosus) and Bolivian Mountain-tanager (Anisognathus flavinucha). HBW Alive Ornithological Note 405. In: Handbook of the Birds of the World Alive. Lynx Edicions, Barcelona. (retrieved from http://www.hbw.com/node/1253799 on 2 December 2016). 